\title{
HOW INFORMATIVE ARE IN-SAMPLE INFORMATION CRITERIA TO FORECASTING? THE CASE OF CHILEAN GDP*
}

\section{Carlos A. Medel ${ }^{* *}$}

This paper compares out-of-sample performance, using the Chilean GDP dataset, of a large number of autoregressive integrated moving average (ARIMA) models with some variations to identify how to achieve the smallest root mean squared forecast error with models based on information criteria - Akaike, Schwarz, and Hannan-Quinn. The analysis also addresses the role of seasonal adjustment and the Easter effect. The results show that Akaike and Schwarz are better criteria for forecasting when using actual series and Schwarz and Hannan-Quinn are better with seasonally adjusted data. Accounting for the Easter effect improves forecast accuracy for actual and seasonally adjusted data.

JEL classification: C13, C22, C52, C53

Keywords: Data mining, forecasting, ARIMA, seasonal adjustment, Easter effect

\section{INTRODUCTION}

An accurate forecast is a key element of successful economic decisionmaking, but there is no standard procedure for selecting a model that systematically outperforms the others at all horizons and with any dataset. A common way to proceed is to choose the best specification within a family of models based on a fitting criterion and then to generate a forecast. In this paper, I compare and evaluate the outof-sample performance of a large number of autoregressive integrated moving average models (ARIMA) chosen according to three commonly used information criteria for model-building: Akaike, Bayesian or Schwarz, and Hannan-Quinn (henceforth AIC, BIC, and HQ), ${ }^{1}$ on a

\footnotetext{
* I would especially like to thank Pablo Pincheira for his comments, support and insights. I am also grateful to Carlos Alvarado, Yan Carrière-Swallow, Francis X. Diebold, Michael Pedersen, Sergio Salgado, Raimundo Soto (editor), Consuelo Edwards, two anonymous referees, and the participants in seminars at Universidad Santo Tomás and the Central Bank of Chile. This is a revised and modified version of Central Bank of Chile Working Paper 657. Any errors or omissions are my own responsibility. The views expressed in this paper do not necessarily represent the opinion of the Central Bank of Chile or its authorities.

** Economic Research Department, Central Bank of Chile. Agustinas 1180, Oficina 451C, Santiago, Chile. Phone: +56 2 3882256. Email: cmedel@bcentral.cl.

1. See Akaike (1974), Shibata (1976), Rissasen (1978), Schwarz (1978), Hannan and Quinn (1979), Lütkepohl (1985), and Koehler and Murphree (1988) for details.
} 
publicly available Chilean GDP dataset without revisions, estimated with a rolling window sample for 1- to 4-steps-ahead forecasts. I also examine the role of seasonal adjustment and the Easter effect on outof-sample performance, whose results are not comparable across all kinds of series (Ghysels, Osborn, and Rodrigues, 2006). The forecast evaluation is based on the root mean squared forecast error (RMSFE) and the Giacomini and White (2006) test. I consider five different aggregation blocks that compound the GDP. I perform this exercise to determine which information criterion leads the forecaster to select the most accurate model.

The goals of this paper are: (i) to investigate the use of the traditional Box-Jenkins approach to find an adequate out-of-sample benchmark for forecasting studies, going beyond the typical naive model; ${ }^{2}$ (ii) to provide an informed opinion on the use of three popular information criteria for forecasting in the Chilean economy and with different aggregations; and (iii) to investigate the accuracy achieved by using seasonally adjusted data and considering the impact of the Easter effect on RMSFE as a parallel exercise. I consider the specific case of the Chilean GDP dataset as a representative case of an economy that has experimented different dynamics throughout a (publicly available) long-sample span. ${ }^{3}$

The forecasts may come from models that explain more than what actually is explained by the data-generating processes, known as overfitting. An overfitted model may have poor predictive performance, as it can exaggerate minor fluctuations in the data. In the context of this paper, the only mechanism to prevent overfitting is the penalty term imposed by each information criterion to the number of regressors included in the model. Thus, I perform the Giacomini and White (2006) test to determine if the mentioned difference in selected model dynamics has a significant impact on RMSFE.

As pointed out by Granger and Jeon (2004), most results from comparing the performance between information criteria are theoretical, and the empirical evidence with actual data on relative forecast accuracy in using each information criterion has not been thoroughly examined.

2. See Box and Jenkins (1970), and Box, Jenkins, and Reinsel (2008) for details about ARMA modeling. 3. Also, the Chilean GDP dataset fulfills other desirable characteristics for model evaluation, as (i) it does not have induced breaks or level shifts due to methodological changes, (ii) it is prepared and released on a quarterly basis, (iii) it is compounded by a number of sectors with different statistical behavior, and (iv) it does not have any missing values, mismatches, or any other shortcoming. 
Granger and Jeon (2001), by comparing the number of regressors chosen according to each information criterion, found that AIC tends to select more dynamic models than the BIC. Further, Clark (2004) proved that the number of (auto)regressors of a model is inversely related to out-of-sample forecast capacity, highlighting the cost of overfitting; this finding was shared with Hansen (2009). This leads us to expect BIC to beat AIC in out-of-sample exercises. Moreover, Granger and Jeon (2004) find that an equally weighted combination between the forecasts delivered by each information criterion increases efficiency. It is intuitive to think of HQ as a combination of AIC and BIC by including a penalization of the number of regressors as well as the asymptotic behavior, suggesting that it may be worth learning about its out-of-sample, model-based features. Notwithstanding, and regardless of some theoretical findings, I treat the matter of which information criterion outperforms the others as an empirical question, the answer to which depends to some extent on the characteristics of the dataset at hand. For example, in the case of Chilean inflation, Cobb (2009) used multivariate, time-series models based on AIC and BIC and found that AIC consistently provided more predictive power. Using the proposed extended SARIMA models, Pincheira and García (2010) also pointed out that AIC gives better predictive results than those chosen with BIC.

This paper also relates to seasonal adjustment and treatments of the Easter effect. I replicate the exercise of choosing the best ARMA model to generate multi-horizon forecasts in the same setting, considering data that has been seasonally adjusted using: (i) the X12-ARIMA methodology, and (ii) explicit regressors (seasonal ARMA models, SARMA). ${ }^{4}$ As pointed out by Granger (1979), since seasonality can contribute substantially to the variance of a series while being economically unimportant, its absence helps to build more parsimonious models with a better fit. More recently, Capistrán, Constandse, and Ramos-Francia (2010) estimated the portion of the Mexican CPI components that was due to seasonality, finding that it can account for almost $80 \%$ of the observed variation. Bell and Sotiris (2010) also showed that certain fundamental choices about seasonal adjustment affect subsequent forecasts by improving their accuracy. I study the impact of the Easter effect - a special feature of seasonal components-

4. The version of X12-ARIMA used in this paper is 0.2.7. A detailed description of the program can be found in Findley et al. (1998) and U.S. Census Bureau (2007). 
on RMSFE in two ways: (i) including the regressors proposed by Bell and Hillmer (1983) in an ARMA environment, and (ii) isolating the seasonal adjustment process prior to modeling, by first including and later excluding the Easter effect using X12-ARIMA. The fundamental reason to make a statement about the out-of-sample impact of the Easter effect, particularly in the Chilean GDP series, lies in the findings of Cobb and Medel (2010) that its exclusion can generate seasonally adjusted series with very different dynamics from those that include it, and because it is information that is known with high confidence several quarters after its realization. Both elements are subjects of interest to an out-of-sample evaluation, and also make the results uncomparable between the different kinds of data.

After the estimation of more than 20 million equations, the results show the following. On average, with actual series, the information criteria that show lower RMSFE across all horizons are AIC and BIC. While AIC forecasts better 1 and 2 steps ahead, BIC does so at the remaining horizons. In the case of seasonally adjusted data, BIC shows better performance 1 and 4 steps ahead, while HQ is the best at the intermediate horizons. In all cases, with and without seasonal adjustment, the differences are not statistically significant.

There is a great deal of literature related to issues raised in this paper, especially on ARMA (unstructured) modeling, conjunctural forecasting (short-term and multi-horizon), seasonal adjustment, Easter-effect treatment, and information criteria for model-building. ${ }^{5}$ Nevertheless, this work follows closely in the spirit of Granger and Jeon (2004) by attempting to reveal the empirical out-of-sample performance of in-sample information criteria using actual data, and in doing so to determine if the behavior is slightly different. Stock and Watson (2007) also studied the performance of many forecasting techniques with 215 macro series from the United States, using ARMA models chosen with information criteria and comparing those with nonlinear models. The results were mixed: Seasonality was found to favor nonlinear models while both AIC and BIC performed better, depending on the type of series employed. ${ }^{6}$

5. A complete recent survey of ARMA modeling and its variants was provided by Holan, Lund, and Davis (2010).

6. A topic not treated in this work is in regard to the different asymptotic properties of each information criterion used in this work. It is important to note that while BIC and HQ are consistent, AIC is not. In short, this implies that as the sample size increases, AIC may change its selected model, converging to the true model. See Nishii (1984) and Canova (2007) for details. 
For the case of Chile, no similar systematic analysis exists on the relative efficiency of information criteria using the same dataset. A related work is Medel and Urrutia (2010), which evaluated the forecasting procedure contained in the X12-ARIMA, but using another criterion (Ljung-Box Q-statistic). The advantage of this automatic procedure is that it filters for outliers and the Easter effect, reducing the variance of the actual series. In this work I also try this procedure to model the seasonally adjusted data, but this filtering makes the results incomparable with unfiltered series.

The paper is organized as follows. In Section 2 I describe the Chilean GDP dataset, the transformations applied to achieve stationarity, the aggregations, and my treatment of seasonality and the Easter effect. In Section 3 I explain the setting for model estimation and in Section 4 I analyze the results for each series by providing a recommendation regarding the information criterion that is most accurate for each of the four horizons considered and for the two kinds of data, based on the minimization of RMSFE. Finally, Section 5 concludes.

\section{DATA}

I use the Central Bank of Chile's Quarterly National Accounts (QNA) starting with GDP as the most aggregated, and with three levels of disaggregation on the demand and supply sides. The original series are in levels, denominated in millions of 2003 Chilean pesos. I use the first release of the QNA that includes 2010.IV, leaving a real-time analysis for further research. ${ }^{7}$ The initial estimation sample covers 1986 .I to 1995.IV (40 observations), and the size of the rolling window is kept fixed. The remaining sample for evaluation covers 1996.I to 2010.III (59 observations).

The series compound the Chilean GDP by demand and supply side. A scheme of demand-side aggregations of all series and the acronyms used in this paper are shown in Table 1, and those of supply-side in Table 2. There is a total of five different aggregations plus the GDP by itself ("aggregation 6"). All five aggregation blocks as well as aggregation 6 deliver a forecast of GDP, calculated as a weighted sum of the forecasts of every corresponding component. The base year for calculating each share is $2003 .^{8}$

7. A framework for a real-time approach that can be used to this end was provided by Clements and Galvão (2010).

8. Table A1 of the appendix displays the shares of every sector on the real GDP at 2003 prices. 


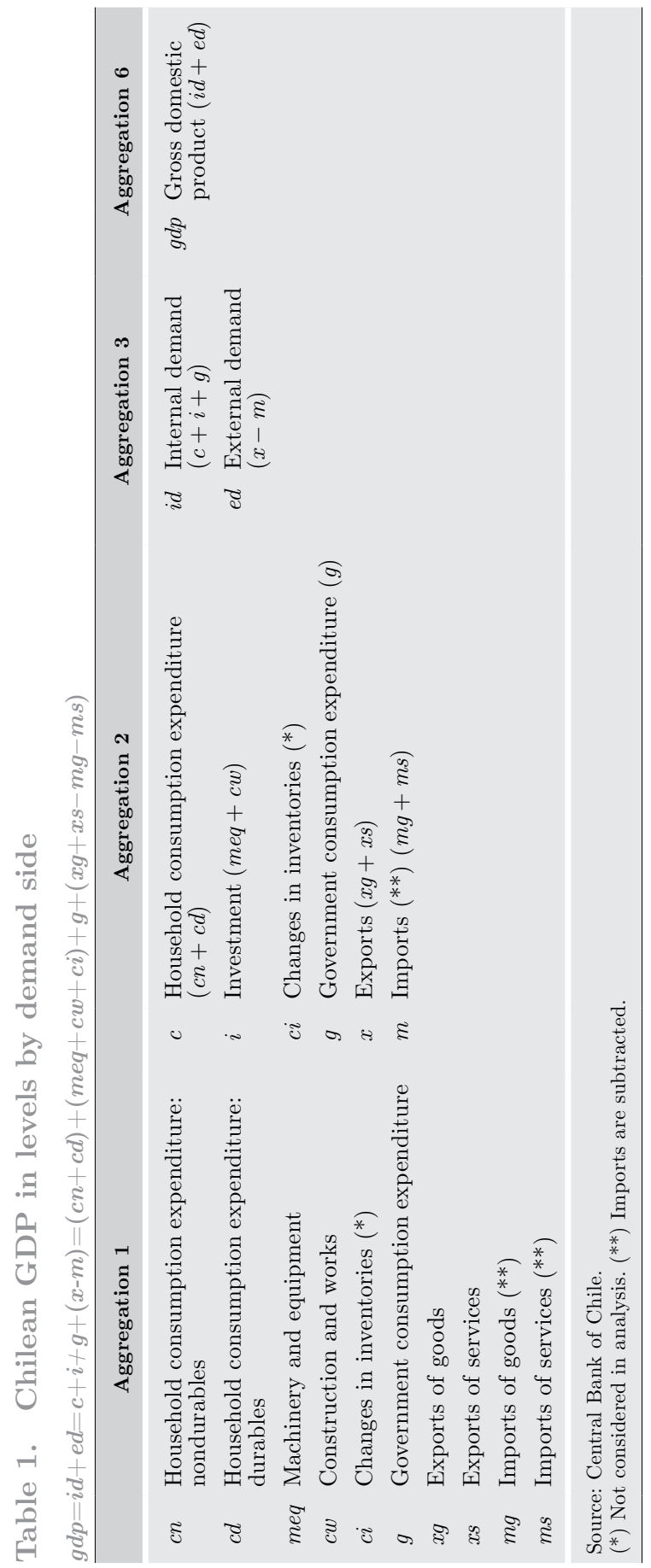




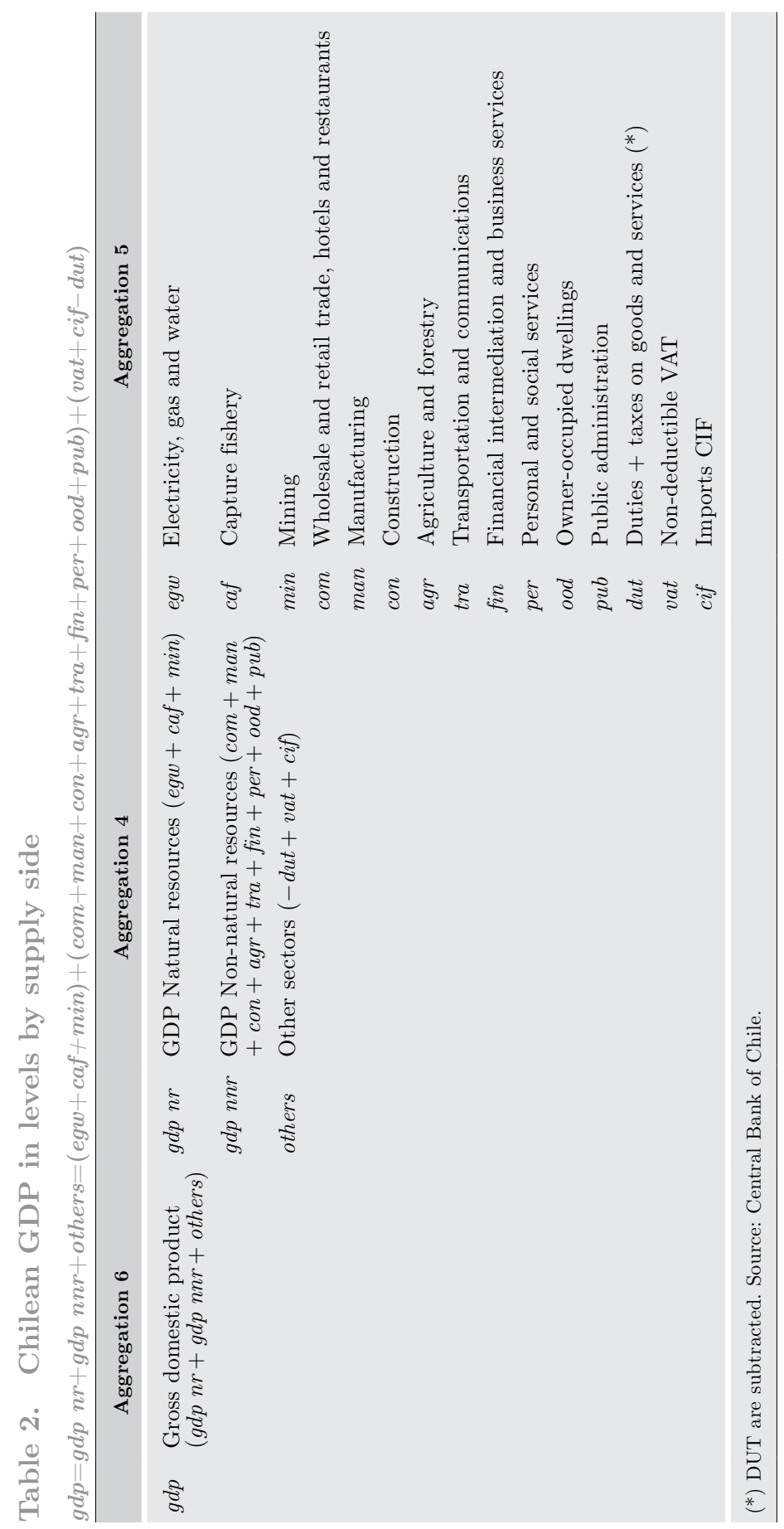


To achieve stationarity I consider the following five transformations: ${ }^{9}$

$$
\begin{gathered}
(i-i v): \Delta^{d} y_{t}=\Delta^{d}\left[\log \left(Y_{t}\right)-\log \left(Y_{t-1}\right)\right], d=\{0, \ldots, 3\}, \\
(v): y_{t}=\left(Y_{t} / Y_{t-4}\right) \cdot 100-100,
\end{gathered}
$$

where $Y_{t}$ is the variable in levels. Hereafter, these transformations are denominated $d 1, d 2, d 3, d 4$, and $\%$. All of these are stationary transformations of the series in levels. By looking at these expressions, econometricians may be apprehensive about the overdifferencing issue. But, this is of minor concern since overdifferencing is mainly a hazard in testing economic theory rather than forecasting (Dickey and Pantula, 1987).

Besides using actual data, the complete exercise is carried out with two kinds of seasonally adjusted data: (i) with special regressors to control for seasonality (SARMA models), and (ii) with the X12 ARIMA procedure. In both cases the Easter effect is considered but in different ways. This effect relates to the fact that the composition of a month or quarter in terms of number of working days affects the dynamics of a series. Typical examples, in the Chilean case, are: retail in September (September 18 is Chilean Independence Day) and December (Christmas and New Year), manufacturing in the summer holiday month of February, and consumption in March (when Chileans must make several one-time annual payments, such as car registration). The Easter effect is considered exogenous as are the variables in ARMAX and SARMAX specifications when the dependent variable is not seasonally adjusted. ${ }^{10}$ The row vector $X_{t}$ contains a set of six series, defined as the number of working days within a quarter minus the number of Sundays within the same period, Day $=\left\{\# \text { Day } y_{t}-\# \text { Sunday }\right\}_{t}$. Bell and Hillmer's (1983) regressors are thus:

$$
X_{t}=\left[\begin{array}{lll}
\text { Monday }_{t} & \ldots & \text { Saturday }_{t}
\end{array}\right] .
$$

The other case with seasonally adjusted data consists of comparisons including and excluding the use of X12-ARIMA, such that the impact of the Easter effect on forecast performance can be isolated. As

9. Table B1 of the appendix shows the typical statistics of all these transformations for all series (panel 1 : demand side; panel 2: supply side).

10. In this context, exogenous means that there is new information being used to model the dependent variable, instead of the case in which it is considered within the seasonal adjustment with X12-ARIMA. In that case it is considered endogenous. 
X12-ARIMA changes the autocorrelation structure of the series, the results when using this treatment are not comparable with those with regressors on actual series.

The treatment of the Easter effect by X12-ARIMA is as follows. ${ }^{11}$ First, the program is an automatic procedure based on moving averages to seasonally adjust economic time series - that is, a separation of a series into a trend-cycle component $\left(T C_{t}\right)$, a seasonal component $\left(S_{t}\right)$, and an irregular component $\left(I_{t}\right)$. This decomposition is typically additive or multiplicative, depending on $I_{t}$ (whether it is really irregular) which is based on a battery of tests contained in the routine. So, assuming an additive decomposition, the series can be split as:

$$
Y_{t}=T C_{t}+S_{t}+I_{t}
$$

where the seasonally adjusted series corresponds to $Y_{t}-S_{t}$. Second, before the application of filters (moving averages) that identify the abovementioned components, X12-ARIMA applies a whitening based on a special module: regARIMA (regression with ARIMA noise), which automatically filters for the Easter effect, leap years, level shifts, additive outliers, transitory changes and ramp, among other considerations. ${ }^{12}$ By doing so, the whitening series added to the seasonally-adjusted series is $\hat{Z}_{t}$, obtained from:

$$
\begin{aligned}
& Y_{t}=\sum_{i} \beta_{i \mid t} C_{i \mid t}+Z_{t}, \\
& \widehat{Z}_{t}=Y_{t}-\sum_{i} \hat{\beta}_{i \mid t} C_{i \mid t,}
\end{aligned}
$$

where $C_{i \mid t}$ is the control $i$, and $\hat{\beta}_{i \mid t}$ is the estimated coefficient associated to the control $i$. This implies that the predicted series is not the actual one, but rather an automatic filtered version. Third, the regressors applied by X12-ARIMA to control for the Easter effect consist of the same Bell and Hillmer regressors used in ARMAX and SARMAX specifications in this work. After identification of all effects, the share excluded by filtering is added to the irregular component to preserve the equality $Y_{t}=T C_{t}+S_{t}+I_{t}$. 


\section{Setting up the estimations}

\subsection{Models}

I estimate six families of models (with intercepts) for each of the five stationarity transformations mentioned above:

Actual series

$$
\begin{aligned}
& \text { (i) : } \operatorname{ARMAX}(p, q) \quad(p, q) \subseteq\{0,1,2,3,4\}^{2}, \\
& (i i): \operatorname{SARMAX}(s, p, q) \quad(p, q) \subseteq\{0,1,2,3,4\}^{2}, s=\{4\}, \\
& (i i i): \operatorname{ARMA}(p, q) \quad(p, q) \subseteq\{0,1,2,3,4\}^{2}, \\
& (i v): \operatorname{SARMA}(s, p, q) \quad(p, q) \subseteq\{0,1,2,3,4\}^{2}, s=\{4\},
\end{aligned}
$$

Seasonally-adjusted series:

$$
\begin{aligned}
& (v): \operatorname{ARMA}(p, q) \quad(p, q) \subseteq\{0,1,2,3,4\}^{2} \\
& \text { (X12 - ARIMA sa with Easter effect), } \\
& \text { (vi): } \operatorname{ARMA}(p, q) \quad(p, q) \subseteq\{0,1,2,3,4\}^{2}
\end{aligned}
$$

I consider the fourth order for frequency considerations; hence, monthly cases are a bit more complicated to compute. ${ }^{13}$ All the estimations were programmed using the ARIMASel add-in for Eviews 7.1. Each model is re-estimated as the rolling window is moved one observation ahead. Each family of models produces a total of 25 (without seasonal regressors) or 36 (with seasonal regressors) models by combining non-skipped $\operatorname{AR}(p), \operatorname{MA}(q), \operatorname{SAR}(s)$ and $\operatorname{SMA}(s)$ regressors with $(p, q) \subseteq\{0,1,2,3,4\}^{2}$ and $s=\{4\}$.

The three information criteria used are as follows:

$$
\begin{aligned}
\mathrm{AIC} & :-2(\ell / T)+2(k / T), \\
\mathrm{BIC} & :-2(\ell / T)+k \log (T) / T, \\
\mathrm{HQ} & :-2(\ell / T)+2 k \log (T) / T,
\end{aligned}
$$


where $\ell$ is the value of the log-likelihood function, with $k$ parameters estimated using $T$ observations. From an empirical viewpoint, the selection of a model depends strictly on how the lag structure in the model fits the series, i.e., how systematic the behavior of the series is across the sample span.

Accounting for five transformations, six specifications, 34 variables, four horizons, three criteria, 28.6 averaged combinations of AR, MA, SAR, SMA regressors, 59 observations within the evaluation window, the number of estimated equations raises:

$$
5 \times 6 \times 34 \times 4 \times 3 \times 28.6 \times 59=20,653,776 \text { equations. }
$$

The number of estimations carried out is slightly lower because in a few cases the value of the log-likelihood function could not be computed.

\subsection{Forecast evaluation}

The evaluation of forecasts is based on comparisons of root mean squared forecast error (RMSFE), defined as:

$$
\operatorname{RMSFE}_{h}=\left[\frac{1}{T(h)} \sum_{t=1}^{T(h)}\left(y_{t+h}-\hat{y}_{t+h \mid t}\right)^{2}\right]^{\frac{1}{2}},
$$

where $\hat{y}_{t}+h$ is the forecast of $y_{t}+h$ (with seasonal correction when appropriate), $h$-quarters ahead ( $h=\{1,2,3,4\}$, and $T(h)$ is the size of the evaluation sample (from 1996.I to 2010.III, and 59 observations for onestep-ahead forecasts). Notwithstanding the transformations, the results are shown and the conclusions made with year-on-year variation of the series in levels. The use of the mean absolute percentage error (MAPE) statistic could be reasonable at this point to avoid homogenization of results and compare it directly, as MAPE is less sensitive to measuring units. But MAPE is more suitable when comparing forecasts of two or more different target series denominated in different units rather than the same predicted variable as in this paper.

I perform the Giacomini and White (2006) test of equal predictive ability to determine if the best model chosen with each information criterion is statistically better than its competitor. As the test is designed for pairwise comparisons, the strategy consists of comparing the best result (lower RMSFE) achieved with (i) AIC versus the BIC, 
(ii) AIC versus HQ, and (iii) finally, BIC versus HQ. Thus, the null $(\mathrm{NH})$ and alternative hypotheses $(\mathrm{AH})$ of the test are:

$$
\begin{aligned}
& \mathrm{NH}: \mathbb{E}\left(d_{i j}^{h}\right)=0, \\
& \mathrm{AH}: \mathbb{E}\left(d_{i j}^{h}\right) \neq 0,
\end{aligned}
$$

where $d_{i j}^{h}$ is the difference of squared forecast error between the best result achieved with the criterion $i$ versus the best result achieved with the criterion $j$, across all forecasts for each horizon $h$ :

$$
d_{i j}^{h}=\left(y_{t+h}-\hat{y}_{t+h \mid t}^{i}\right)^{2}-\left(y_{t+h}-\hat{y}_{t+h \mid t}^{j}\right)^{2} .
$$

The null hypothesis is rejected at a significance level of $\alpha \%$ if the calculated statistic $\left(G W_{h}\right)$ :

$$
G W^{h}=\frac{\bar{d}_{i t}^{h}}{\hat{\sigma}_{d_{i t}^{h}} / \sqrt{T(h)}},
$$

is bigger than $\delta$, where $\delta$ is a value obtained from the percentile $\alpha \% / 2$ of a normal standard distribution. Note that $\hat{\sigma}_{d_{i j}^{h}}$ is a heteroskedasticity and autocorrelation-corrected estimation of the standard deviation of $d_{i j}^{h}$ (Newey and West, 1987).

\section{Results}

This section shows the results of the most accurate forecast achieved by each information criterion, given its type of model, aggregation, and stationary transformation, for both kinds of data. It is worth mentioning that the results obtained are fully computer-based, implying that extreme forecasts are not trimmed by the judgment of the forecaster. ${ }^{14}$ Thus, the RMSFE results can be easily improved, avoiding such "crazy" forecasts by allowing for a "no change" forecast $\left(y_{t+h \mid t}=y_{t}\right)$ given a threshold, as used by Stock and Watson (2007). I opt not to intervene to ensure a fairer comparison of the information criteria, and because an intervention could result in important effects on accuracy and inference as highlighted by Mélard and Pasteels (2000). 
There are two kinds of results: with and without seasonal adjustment, to allow for fair comparison of the RMSFE for the same dependent variable. I also report some results on models, aggregations, and stationary transformations as special topics.

\subsection{Results of actual series}

Tables 3 to 6 show the RMSFE estimates for $h=1$ to 4 obtained with actual series. Note that some cells of the tables show a value of " $>100$ " implying the presence of outliers in sector forecasts or in the GDP itself (Aggregation 6). These outliers are due to data and/or numerical misestimation of the log-likelihood function. As X12-ARIMA filters the series for outliers, among other anomalies, this kind of result is not present with seasonally adjusted data.

From Table 3, we see that for $h=1$ the best results are obtained with AIC, achieving a RMSFE of 1.87, followed closely by BIC with 1.90, and finally $\mathrm{HQ}$ with 1.92 . The same qualitative result holds true for $h=2$. Table 4 show that the minimum RMSFE is 1.81 , followed by 1.87, and finally 1.89, in the same order: AIC, BIC, and HQ. For $h=3$ there is virtually a tie between the BIC and AIC, showing an RMSFE of 1.75 and 1.76, respectively. Lastly, HQ shows a RMSFE of 1.93. For one-year ahead the same situation occurs as for $h=3$ : BIC and AIC show an RMSFE of 1.50 and 1.51, respectively. Finally, HQ achieves an 1.63 in RMSFE.

As shown in Table 11 (upper panel), the results of the Giacomini and White (2006) test reveal that there are no significant statistical differences among the results of each horizon for the three information criteria. But despite this finding and based purely on RMSFE, the recommendation is that AIC be used for short horizons and BIC for intermediate horizons shorter than one year when predicting actual series.

\subsection{Results of seasonally adjusted series}

Tables 7 to 10 show the RMSFE estimates for $h=1$ to 4 obtained with the seasonally adjusted series. The only difference from the other series, as previously mentioned, is the treatment of the Easter effect. The upper panels of Tables 7 through 10 show the results considering the row vector $\mathbf{X}$ of working days and holidays within the adjusting process ("With E-e"). The lower panel, conversely, does not control for working days and only accounts for the remaining anomalies listed in Section 2. 


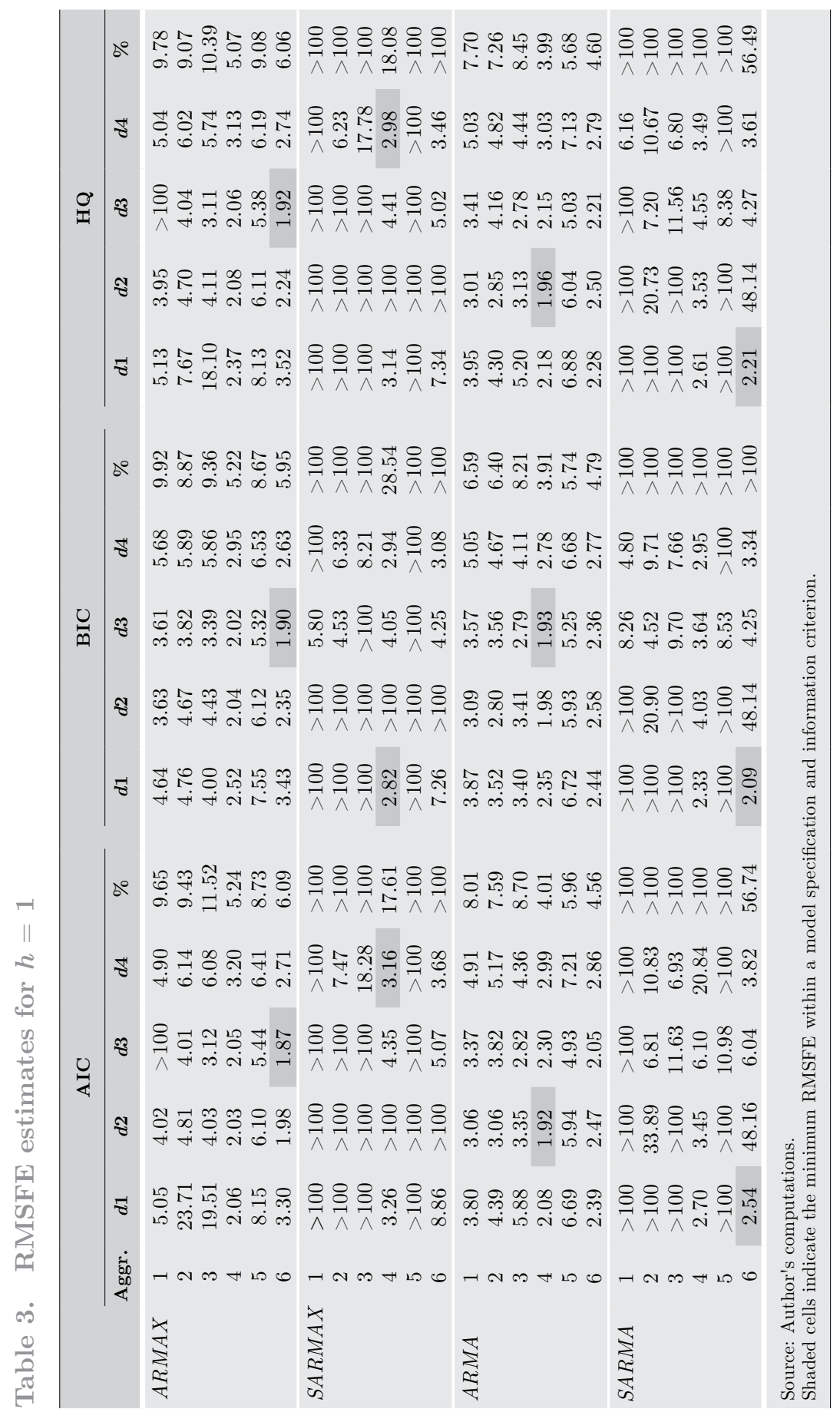




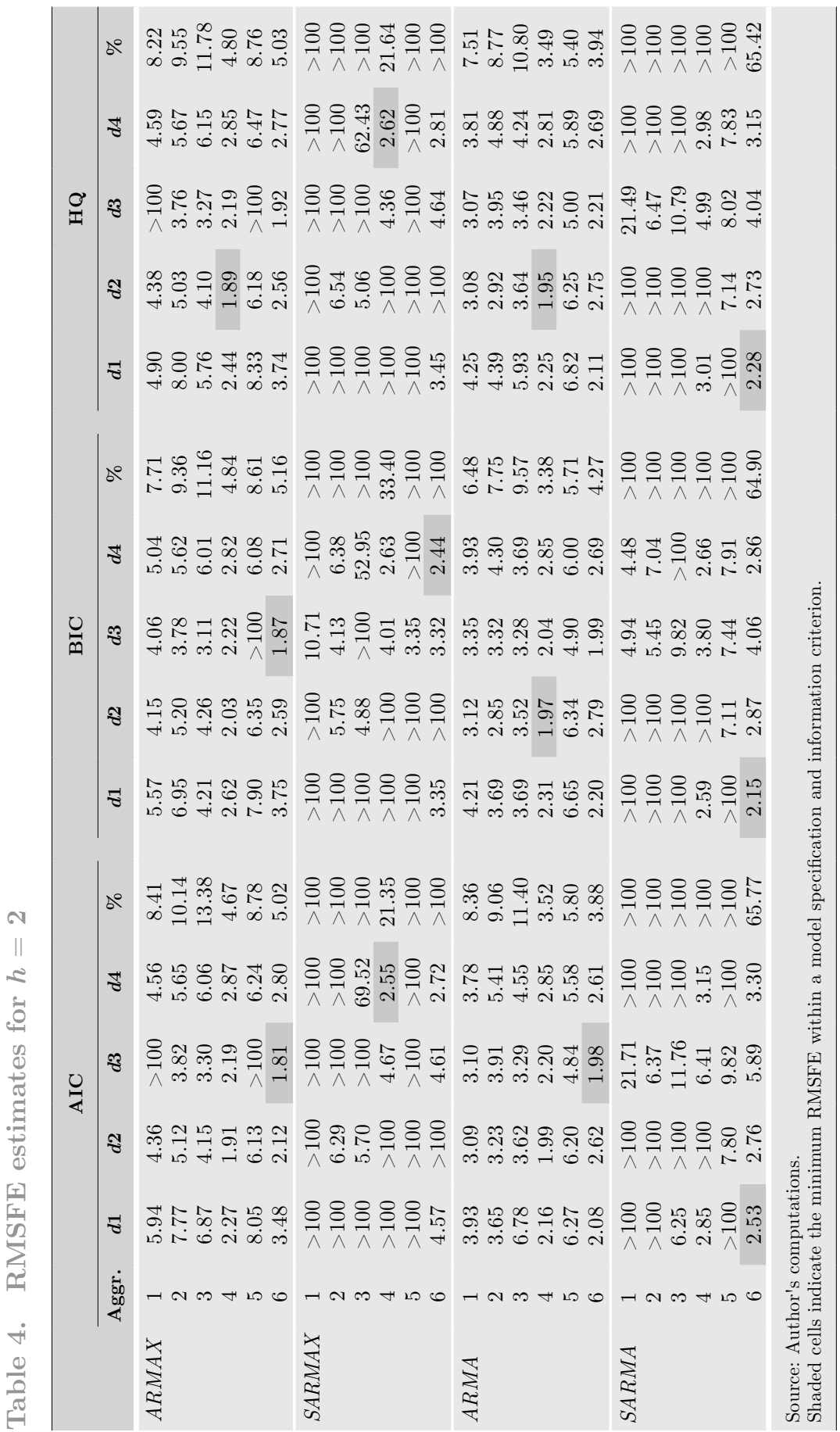


¿

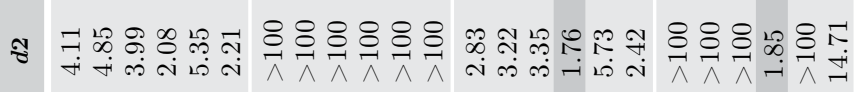

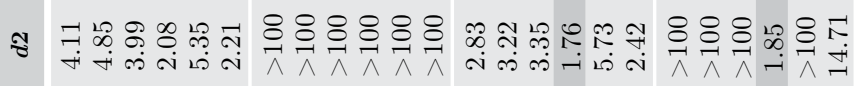
ร ᄂ เ

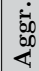

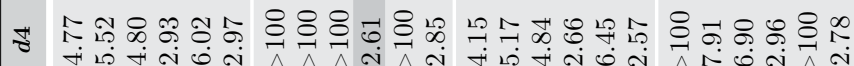

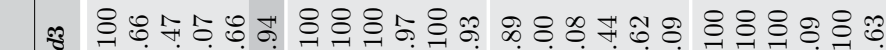

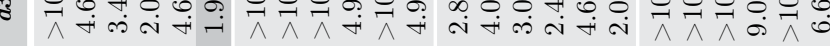
thm

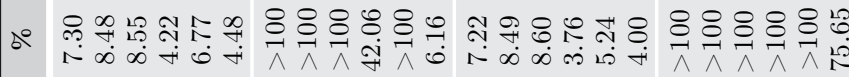

ร

我

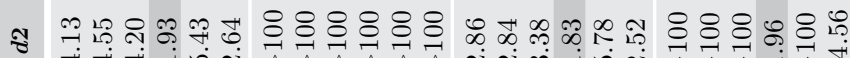

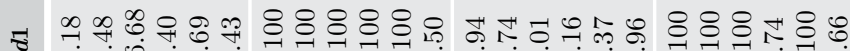

๙゚

ป

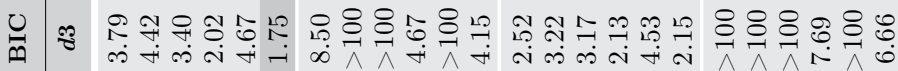

ชิ

ஏ

แ 


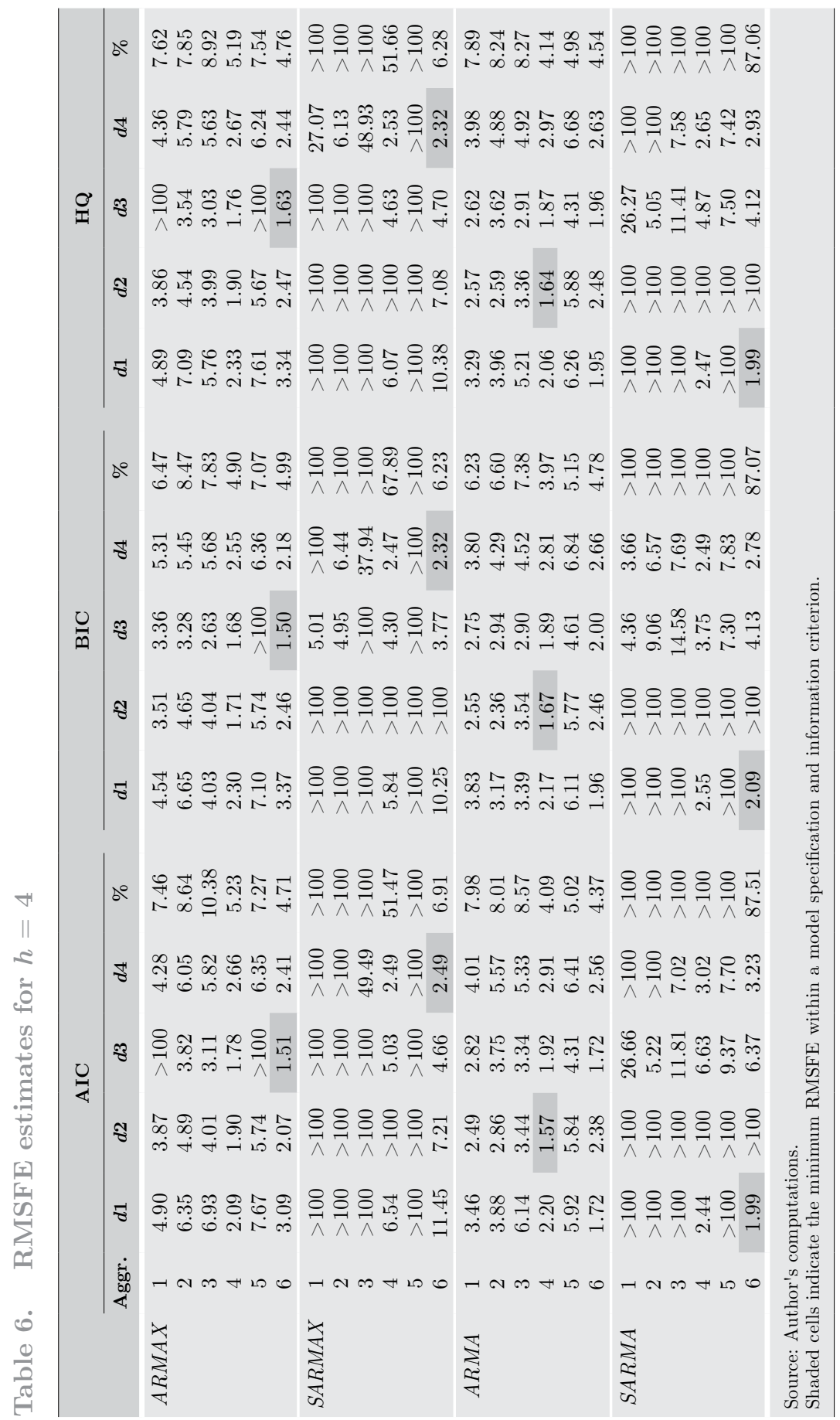




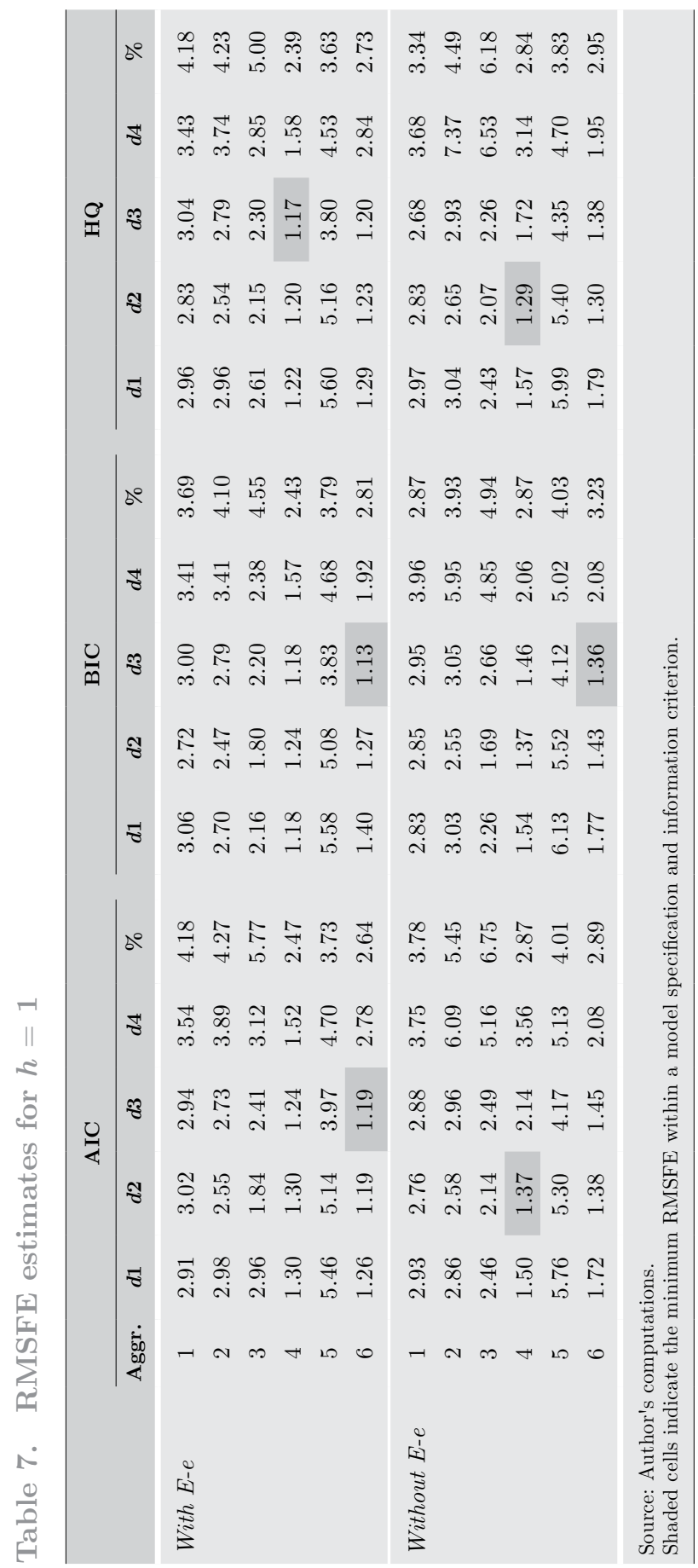




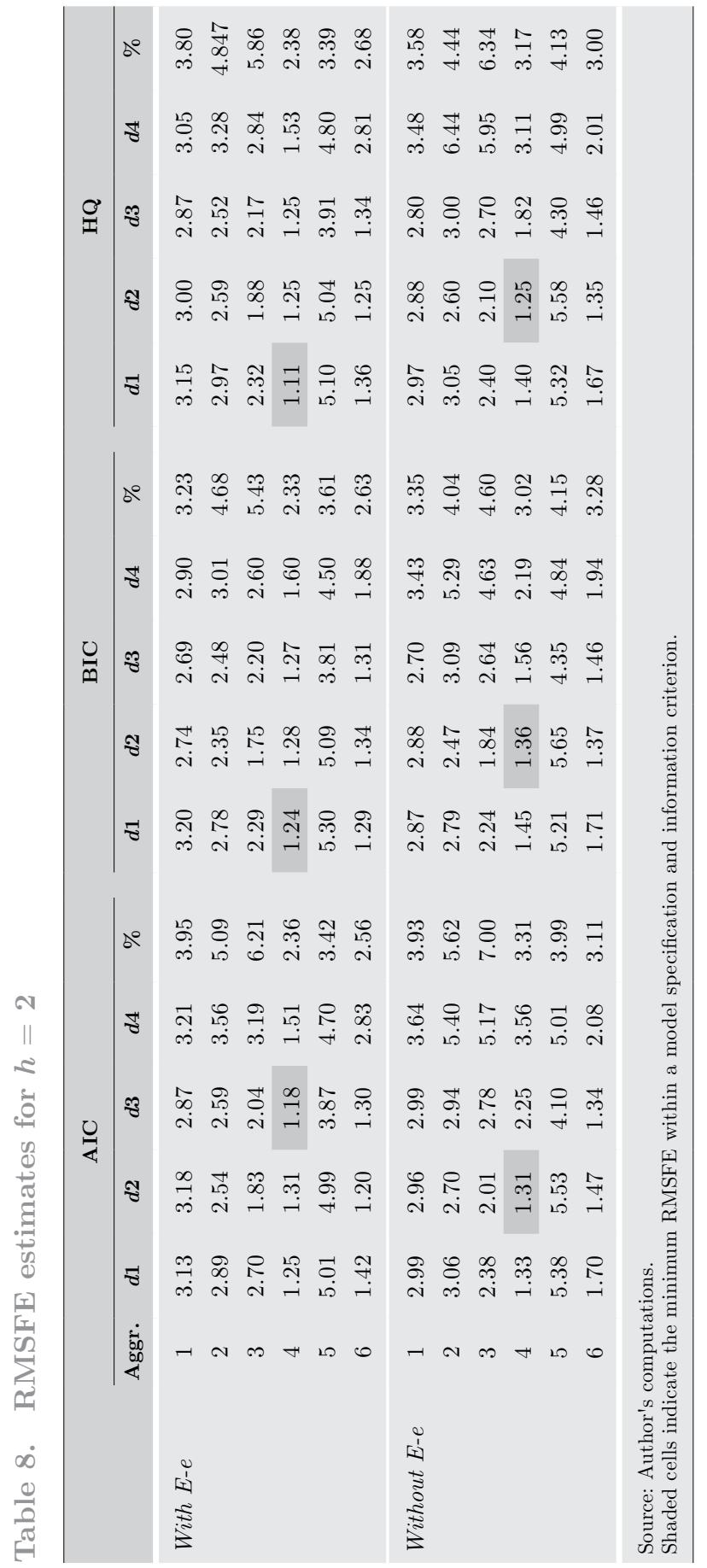




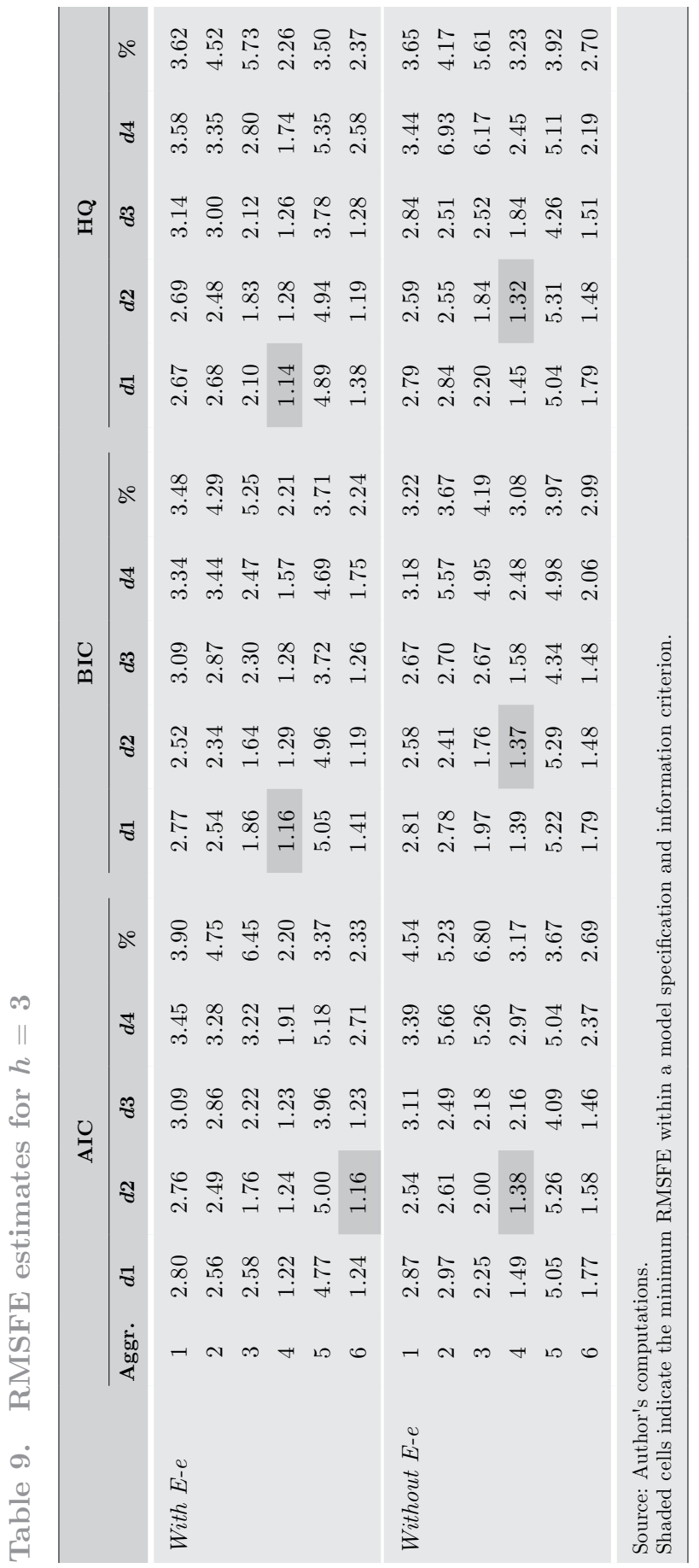




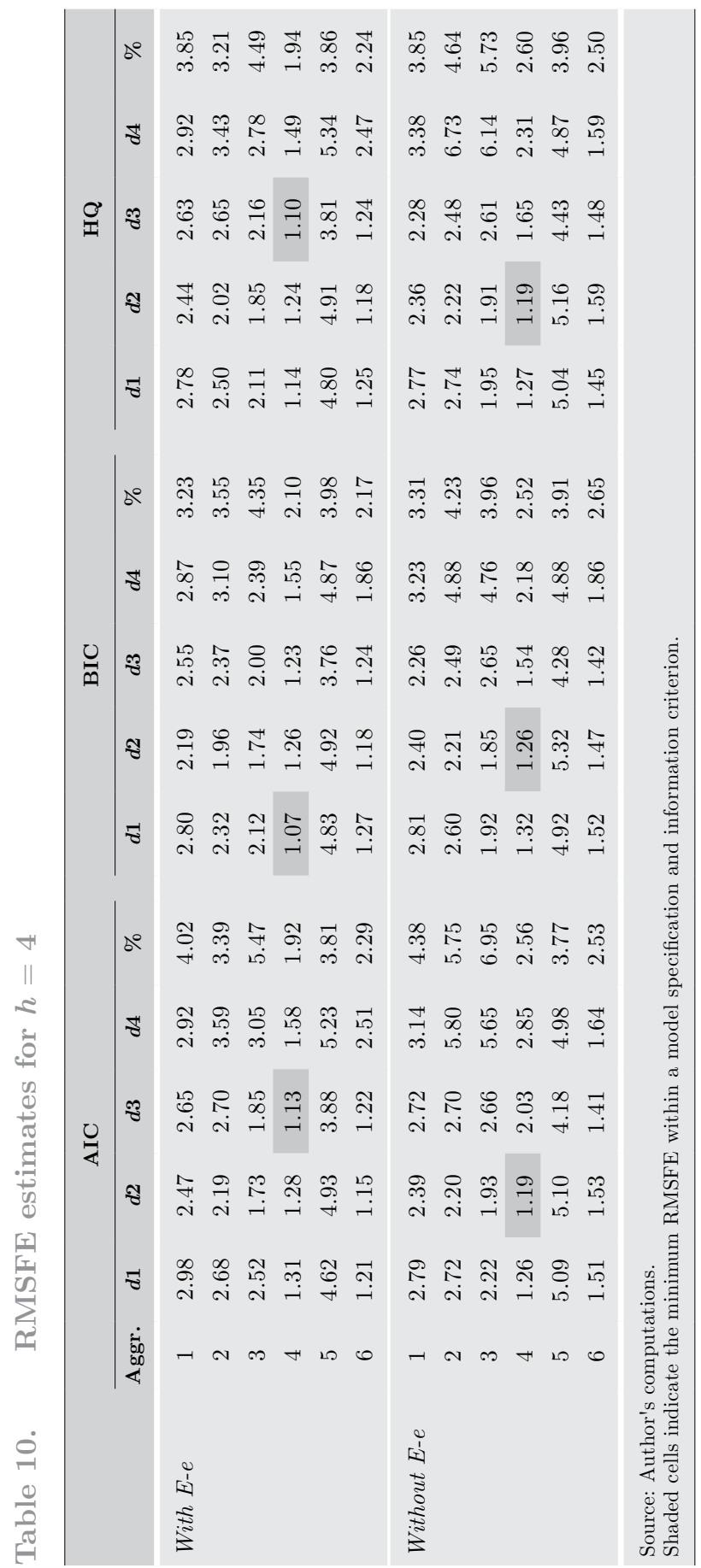


Table 11. Giacomini and White (2006) test results

\begin{tabular}{|c|c|c|c|c|}
\hline \multicolumn{2}{|c|}{ Null Hypothesis: } & $\mathrm{AIC}$ vs BIC & AIC vs HQ & BIC vs HQ \\
\hline \multicolumn{5}{|c|}{ Actuals } \\
\hline \multirow[t]{2}{*}{$h=1$} & GW core stat & 0.000 & 0.000 & 0.000 \\
\hline & $p$-value & 0.962 & 0.904 & 0.795 \\
\hline \multirow[t]{2}{*}{$h=2$} & GW core stat & 0.000 & 0.000 & 0.000 \\
\hline & $p$-value & 0.423 & 0.817 & 0.701 \\
\hline \multirow[t]{2}{*}{$h=3$} & GW core stat & 0.000 & 0.000 & 0.000 \\
\hline & $p$-value & 0.676 & 0.195 & 0.820 \\
\hline \multirow[t]{2}{*}{$h=4$} & GW core stat & 0.000 & 0.000 & 0.000 \\
\hline & $p$-value & 0.792 & 0.368 & 0.450 \\
\hline \multicolumn{5}{|c|}{ Seasonally adjusted } \\
\hline \multirow[t]{2}{*}{$h=1$} & GW core stat & 0.000 & 0.000 & 0.000 \\
\hline & $p$-value & 0.253 & 0.667 & 0.269 \\
\hline \multirow[t]{2}{*}{$h=2$} & GW core stat & 0.000 & 0.000 & 0.000 \\
\hline & $p$-value & 0.734 & 0.384 & 0.074 \\
\hline \multirow{2}{*}{$h=3$} & GW core stat & 0.000 & 0.000 & 0.000 \\
\hline & $p$-value & 0.373 & 0.309 & 0.636 \\
\hline \multirow{2}{*}{$h=4$} & GW core stat & 0.000 & 0.000 & 0.000 \\
\hline & $p$-value & 0.456 & 0.472 & 0.682 \\
\hline
\end{tabular}

The result suggests that exclusion of the Easter effect was not helpful in terms of accuracy in any of the cases, in line with the in-sample findings of Cobb and Medel (2010). For $h=1$ and 4, the best results are obtained with BIC, and for the remaining horizons with HQ. For $h=1$, BIC achieves an RMSFE of 1.13, followed by HQ with 1.17 , and AIC with 1.19. For $h=2$, the best result is obtained with HQ, showing an RMSFE of 1.11, then AIC with 1.18, and lastly, BIC with 1.24. For $h=3 \mathrm{HQ}$ achieves an RMSFE of 1.14, tied with AIC, followed by BIC with 1.16. Lastly, for $h=4$, the best result is obtained with BIC for an RMSFE of 1.07, then HQ with 1.10, and finally AIC with 1.13. According to Table 11 (lower panel), there is only one case in which the difference among the two information criteria is statistically different at a $10 \%$ level of confidence: BIC and $\mathrm{HQ}$ at $h=2$. 
Table 12. Summary of findings

\begin{tabular}{|c|c|c|c|c|c|c|c|c|}
\hline & $h=1$ & $h=\mathbf{2}$ & $h=\mathbf{3}$ & $h=4$ & $h=1$ & $h=\mathbf{2}$ & $h=\mathbf{3}$ & $h=4$ \\
\hline & \multicolumn{4}{|c|}{ Actuals } & \multicolumn{4}{|c|}{ Seasonally adjusted } \\
\hline & \multicolumn{8}{|c|}{ Model } \\
\hline$A R M A X$ & (1)(2)(3) & (1)(2)(3) & (1) & (1)(2)(3) & $\boldsymbol{*}$ & * & 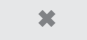 & $\boldsymbol{*}$ \\
\hline$S A R M A X$ & - & - & - & - & * & * & $\boldsymbol{x}$ & $\mathbf{x}$ \\
\hline$A R M A$ & - & - & (2) (3) & - & * & * & $\boldsymbol{x}$ & x \\
\hline$S A R M A$ & - & - & - & - & $x$ & * & $x$ & $x$ \\
\hline$A R M A$ & $*$ & $*$ & $\boldsymbol{*}$ & $*$ & (1)(2)(3) & (1)(2)(3) & (1)(2)(2) & (1)(2) (3) \\
\hline \multirow[t]{2}{*}{$A R M A$} & * & x & $*$ & $\boldsymbol{x}$ & - & - & - & - \\
\hline & \multicolumn{8}{|c|}{ Transformation } \\
\hline$d 1$ & - & - & - & - & - & (1) (3) & (1)(2) & (1) \\
\hline$d^{2}$ & - & (3) & (2) (3) & - & - & - & (2) & - \\
\hline$d 3$ & (1)(2)(3) & (1)(2) & (1) & (1)(2)(3) & (1)(2) (3) & (2) & - & (2) (3) \\
\hline$d 4$ & - & - & - & - & - & - & - & - \\
\hline \multirow[t]{2}{*}{$\%$} & - & - & - & - & - & - & - & - \\
\hline & \multicolumn{8}{|c|}{ Aggregation } \\
\hline 1 & - & - & - & - & - & - & - & - \\
\hline 2 & - & - & - & - & - & - & - & - \\
\hline 3 & - & - & - & - & - & - & - & - \\
\hline 4 & - & (3) & (2) (3) & - & (2) & (1)(2)(3) & (1)(2) & (1) (2) (3) \\
\hline 5 & - & - & - & - & - & - & - & - \\
\hline 6 & (1)(2)(3) & (1)(2) & (1) & (1)(2) (3) & (1) (3) & - & (2) & - \\
\hline
\end{tabular}

Finally, when using seasonally adjusted data, the recommendation is to base the model selection for forecasting purposes on BIC when predicting at one and four steps ahead and HQ for the horizons in between. Also, it is recommended that the Easter effect (the Chilean calendar) always be included in the estimates.

\subsection{Special issues: models, aggregations, and transformations}

Besides the information criteria results, I treat some elements related to the estimation as an additional topic. These elements are the kinds of models, aggregations, and transformations to achieve stationarity used to determine which information criterion is best for forecasting. In Table 12, I transcribe the information of the aforementioned elements 
from Tables 3 to 10 by locating the three best results for the three information criteria analyzed, by each horizon, in the corresponding cell for model, transformation, and aggregation.

The results regarding models reveal that it is always desirable, for all horizons, to include the Easter effect with both actual and seasonally adjusted data. Note that for all horizons the first three places are

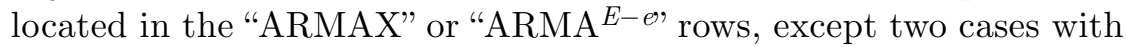
the actual series at $h=3$. Regarding data transformations, with actual series it is clear that the third order of differencing is preferred, as well as with seasonally adjusted data at $h=1$. For the remaining horizons, with seasonally adjusted data, the first order of differencing delivers the most accurate results. A similar situation occurs with aggregations. With actual data it is clear that aggregation 6 (the GDP alone) shows the best results, and the same is true for seasonally adjusted data at $h=1$. For $h=2$ to 4 , with the latter kind of data, aggregation 4 , that is, the weighted sum of supply components at one level of disaggregation, should be used.

\section{CONCluding Remarks}

The main aim of this paper is to identify which of three commonly used information criteria has the highest predictive power to forecast Chilean GDP and its components. Over 20 million ARMA models were estimated using stationary transformations of the original series. Then computer-based, non-trimmed projections from one to four steps ahead were developed using a rolling window estimation scheme for a sample of 59 observations. The effect of seasonality and the impact of the Easter effect on the RMSFE were also investigated.

The results show that, on average, with actual series the information criteria that show lower RMSFE across all horizons are AIC and BIC. While AIC forecasts better one and two steps ahead, BIC is better at the remaining horizons.

In the case of seasonally adjusted data, BIC shows better performance one and four steps ahead, while HQ is the best at intermediate horizons. In all cases, with and without seasonal adjustment, the differences are not statistically significant. Accounting for the Easter effect improves the forecast accuracy for both actual and seasonally adjusted data. 


\section{REFERENCES}

Akaike, H. (1974), "A new look at the statistical model identification," IEEE Transactions on Automatic Control 19(6): 716-23.

Bell, W.R. and S.C. Hillmer (1983), "Modelling time series with calendar variation," Journal of the American Statistical Association 78: 526-34.

Bell, W.R. and E. Sotiris (2010), "Seasonal adjustment to facilitate forecasting: Empirical results," Research Staff Papers, U.S. Census Bureau.

Box, G.E.P. and G.M. Jenkins (1970), Time series analysis: Forecasting and control, San Francisco: Holden-Day.

Box, G.E.P., G.M. Jenkins and G.C. Reinsel (2008), Time series analysis: Forecasting and control (4th ed.), New York: Wiley.

Canova, F. (2007), Methods for applied macroeconomic research, Princeton: Princeton University Press.

Capistrán, C., C. Constandse, and M. Ramos-Francia (2010), "Multi-horizon inflation forecasts using disaggregated data," Economic Modelling 27(3): 666-77.

Clark, T.E. (2004), "Can out-of-sample forecast comparisons help prevent overfitting?" Journal of Forecasting 23(2): 115-39.

Clements, M.P. and A.B. Galvão (2010), "Real-time forecasting of inflation and output growth in the presence of data revisions," the Warwick Economics Research Paper Series 953, Department of Economics, University of Warwick, United Kingdom.

Cobb, M. (2009), "Forecasting Chilean inflation from disaggregate components," Central Bank of Chile Working Paper 545.

Cobb, M. and C.A. Medel (2010), "Una estimación del impacto del efecto calendario en series desestacionalizadas chilenas de actividad y demanda" [An estimation of the impact of the calendar effect in seasonally adjusted Chilean activity and demand series], Revista Economía Chilena 13(3): 95-103.

Dickey, D.A. and S.G. Pantula (1987), "Determining the order of differencing in autoregressive processes," Journal of Business and Economic Statistics 5(4): $455-61$.

Findley, D.F., B.C. Monsell, W.R. Bell, M.C. Otto, and B. Chen (1998), "New capabilities and methods of the X12-ARIMA seasonal adjustment program," Journal of Business and Economics Statistics 16(2): 127-52.

Ghysels, E., D. Osborn, and P.M.M. Rodrigues (2006), "Forecasting seasonal time series," in G. Elliot, C.W.J. Granger and A. Timmermann (eds.), Handbook of economic forecasting, North Holland: Elsevier.

Giacomini, R. and H. White (2006), "Test of conditional predictive ability," Econometrica 74: 1545-78.

Goodwin, P., D. Önkal, and M. Lawrence (2011), "Improving the role of judgment in economic forecasting," in M. Clements and D.F. Hendry (eds.), The Oxford handbook of economic forecasting, Oxford: Oxford University Press. 
Granger, C.W.J. (1979), "Seasonality: causation, interpretation, and implications," in A. Zellner (ed.), Seasonal analysis of economic time series, Cambridge, MA: National Bureau of Economic Research.

Granger, C.W.J. and Y. Jeon (2001), "The roots of US macro time series," Working Paper, University of California at San Diego.

Granger, C.W.J. and Y. Jeon 2004, "Forecasting performance of information criteria with many macro series," Journal of Applied Statistics 31(10): 1227-40.

Hannan, E.J. and B.G. Quinn (1979), "The determination of the order of an autoregression," Journal of the Royal Statistical Society B41: 190-5.

Hansen, P.R. (2009), "In-sample fit and out-of-sample fit: Their joint distribution and its implications for model selection," preliminary version April 23, 2009, Department of Economics, Stanford University.

Holan, S.H., R. Lund, and G. Davis (2010), "The ARMA alphabet soup: A tour of ARMA model variants," Statistics Surveys 4: 232-74.

Koehler, A.B. and E.S. Murphree (1988), "A comparison of the Akaike and Schwarz criteria for selecting model order," Journal of the Royal Statistical Society, Series C (Applied Statistics) 37(2): 187-95.

Lütkepohl, H. (1985), "Comparison of criteria for estimating the order of a vector autoregressive process," Journal of Time Series Analysis 6(1): 35-52.

Medel, C.A. and M. Urrutia (2010), "Proyección agregada y desagregada del PIB chileno con procedimientos automatizados de series de tiempo" [Aggregated and disaggregated forecast of Chilean GDP with automatic time series procedures], Central Bank of Chile Working Paper 577.

Mélard, G. and J.M. Pasteels (2000), "Automatic ARIMA modeling including interventions, using time series expert software," International Journal of Forecasting 16(4): 497-508.

Newey, W. and K. West (1987), "A simple, positive semi-definite, heteroskedasticity and autocorrelation-consistent covariance matrix," Econometrica 55(3): 703-8.

Nishii, R. (1984), "Asymptotic properties of criteria for selection of variables in multiple regression," Annals of Statistics 12(2): 758-65.

Pincheira, P. and A. García (2009), "Forecasting inflation in Chile with an accurate benchmark," Central Bank of Chile Working Paper 514.

Rissasen, J. (1978), "Modeling by shortest data description," Automatica 14(5): 465-71.

Schwarz, G.E. (1978), "Estimating the dimension of a model," Annals of Statistics 6(2): 461-64.

Shibata, R. (1976), "Selection of the order of an autoregressive model by Akaike information criterion," Biometrika 63(1): 117-26.

Stock, J. and M. Watson (2007), "A comparison of linear and nonlinear univariate models for forecasting macroeconomic time series," in R.E. Engle and H. White (eds.), Cointegration, causality, and forecasting: A festschrift in honour of Clive W.J. Granger, Oxford: Oxford University Press.

U.S. Census Bureau, 2007, X12-ARIMA version 0.3 Reference Manual, available at http://www.census.gov/ts/x12a/v03/x12adocV03.pdf. 


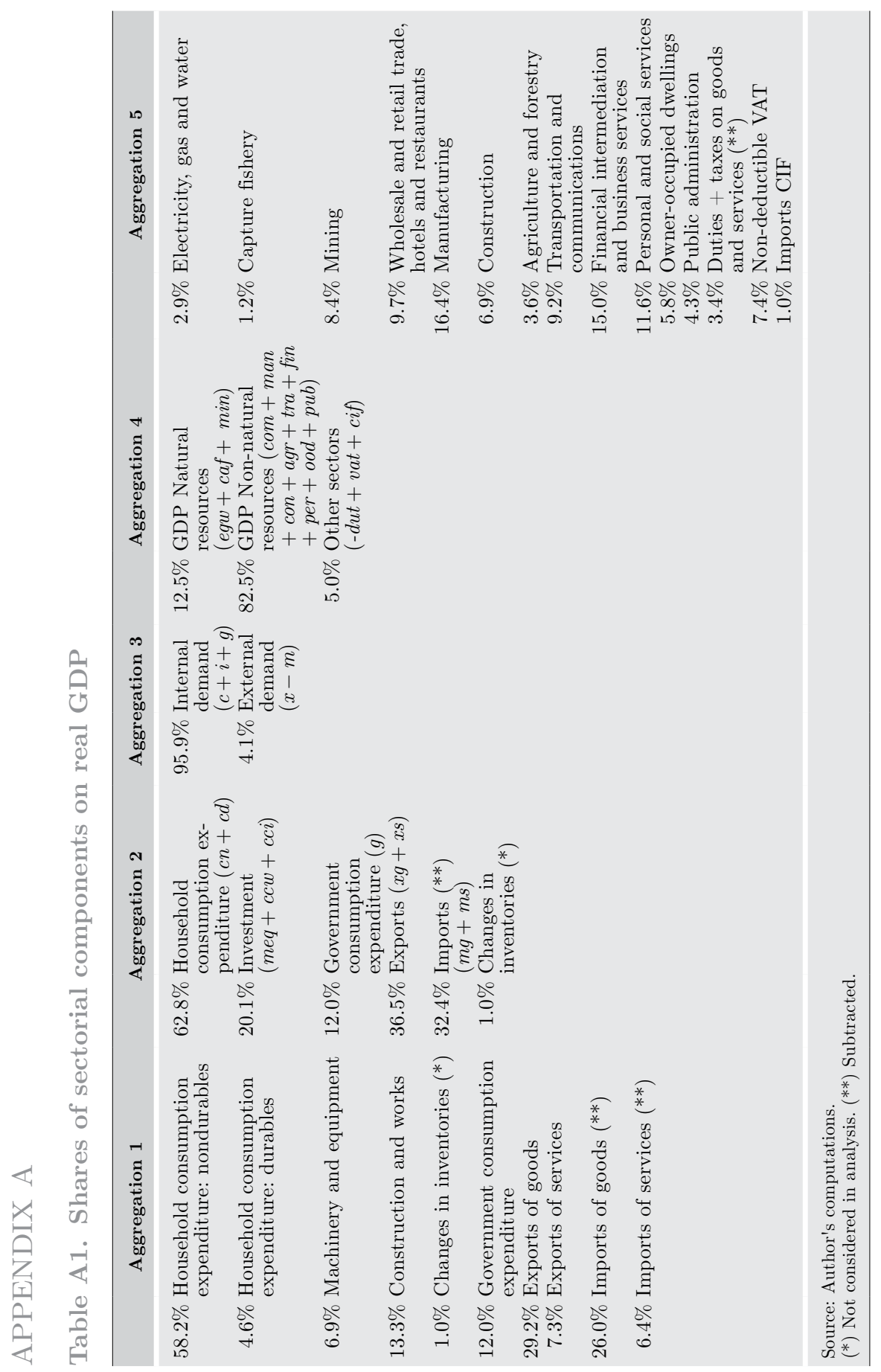




\section{APPENDIX B}

Table B1. Typical statistics of demand side series, full sample

\begin{tabular}{|c|c|c|c|c|c|c|c|c|c|c|}
\hline & \multicolumn{5}{|c|}{$\begin{array}{c}\text { Mean } \\
\text { (Standard deviation) }\end{array}$} & \multicolumn{5}{|c|}{$\begin{array}{c}\text { Maximum } \\
\text { (Minimum) }\end{array}$} \\
\hline & $d 1$ & $d 2$ & $d 3$ & $d 4$ & $\%$ & $d 1$ & $d 2$ & $d \mathbf{3}$ & $d 4$ & $\%$ \\
\hline$c n$ & $\begin{array}{c}0.014 \\
(0.054)\end{array}$ & $\begin{array}{c}0.000 \\
(0.100)\end{array}$ & $\begin{array}{c}0.001 \\
(0.194)\end{array}$ & $\begin{array}{l}-0.003 \\
(0.381)\end{array}$ & $\begin{array}{c}0.058 \\
(0.029)\end{array}$ & $\begin{array}{c}0.135 \\
(-0.084)\end{array}$ & $\begin{array}{c}0.172 \\
(-0.203)\end{array}$ & $\begin{array}{c}0.331 \\
(-0.358)\end{array}$ & $\begin{array}{c}0.670 \\
(-0.634)\end{array}$ & $\begin{array}{r}0.157 \\
(-0.018)\end{array}$ \\
\hline$c d$ & $\begin{array}{c}0.033 \\
(0.152)\end{array}$ & $\begin{array}{c}-0.006 \\
(0.247)\end{array}$ & $\begin{array}{c}0.003 \\
(0.449)\end{array}$ & $\begin{array}{l}-0.021 \\
(0.845)\end{array}$ & $\begin{array}{c}0.139 \\
(0.209)\end{array}$ & $\begin{array}{c}0.582 \\
(-0.341)\end{array}$ & $\begin{array}{c}0.637 \\
(-0.695)\end{array}$ & $\begin{array}{c}1.019 \\
(-1.002)\end{array}$ & $\begin{array}{c}1.267 \\
(-1.909)\end{array}$ & $\begin{array}{c}0.769 \\
(-0.361)\end{array}$ \\
\hline meq & $\begin{array}{c}0.031 \\
(0.114)\end{array}$ & $\begin{array}{c}-0.002 \\
(0.175)\end{array}$ & $\begin{array}{l}-0.005 \\
(0.313)\end{array}$ & $\begin{array}{l}-0.009 \\
(0.584)\end{array}$ & $\begin{array}{c}0.147 \\
(0.207)\end{array}$ & $\begin{array}{c}0.310 \\
(-0.384)\end{array}$ & $\begin{array}{c}0.382 \\
(-0.423)\end{array}$ & $\begin{array}{c}0.714 \\
(-0.746)\end{array}$ & $\begin{array}{c}1.215 \\
(-1.199)\end{array}$ & $\begin{array}{c}0.645 \\
(-0.319)\end{array}$ \\
\hline$c w$ & $\begin{array}{c}0.014 \\
(0.080)\end{array}$ & $\begin{array}{c}0.000 \\
(0.120)\end{array}$ & $\begin{array}{c}-0.002 \\
(0.199)\end{array}$ & $\begin{array}{c}-0.005 \\
(0.349)\end{array}$ & $\begin{array}{c}0.062 \\
(0.096)\end{array}$ & $\begin{array}{c}0.203 \\
(-0.176)\end{array}$ & $\begin{array}{c}0.263 \\
(-0.235)\end{array}$ & $\begin{array}{c}0.342 \\
(-0.438)\end{array}$ & $\begin{array}{c}0.702 \\
(-0.617)\end{array}$ & $\begin{array}{c}0.327 \\
(-0.218)\end{array}$ \\
\hline$g$ & $\begin{array}{c}0.011 \\
(0.117)\end{array}$ & $\begin{array}{c}-0.001 \\
(0.197)\end{array}$ & $\begin{array}{c}-0.001 \\
(0.350)\end{array}$ & $\begin{array}{l}-0.007 \\
(0.652)\end{array}$ & $\begin{array}{c}0.041 \\
(0.023)\end{array}$ & $\begin{array}{c}0.199 \\
(-0.182)\end{array}$ & $\begin{array}{c}0.357 \\
(-0.184)\end{array}$ & $\begin{array}{c}0.517 \\
(-0.536)\end{array}$ & $\begin{array}{c}0.663 \\
(-1.046)\end{array}$ & $\begin{array}{c}0.086 \\
(-0.039)\end{array}$ \\
\hline$x g$ & $\begin{array}{c}0.017 \\
(0.102)\end{array}$ & $\begin{array}{l}-0.002 \\
(0.154)\end{array}$ & $\begin{array}{c}0.004 \\
(0.241)\end{array}$ & $\begin{array}{l}-0.004 \\
(0.392)\end{array}$ & $\begin{array}{c}0.073 \\
(0.071)\end{array}$ & $\begin{array}{c}0.235 \\
(-0.213)\end{array}$ & $\begin{array}{c}0.364 \\
(-0.363)\end{array}$ & $\begin{array}{c}0.639 \\
(-0.613)\end{array}$ & $\begin{array}{c}1.076 \\
(-0.981)\end{array}$ & $\begin{array}{c}0.246 \\
(-0.065)\end{array}$ \\
\hline$x s$ & $\begin{array}{c}0.016 \\
(0.383)\end{array}$ & $\begin{array}{c}0.014 \\
(0.580)\end{array}$ & $\begin{array}{c}-0.011 \\
(0.954)\end{array}$ & $\begin{array}{c}0.003 \\
(1.686)\end{array}$ & $\begin{array}{c}0.130 \\
(0.291)\end{array}$ & $\begin{array}{c}1.290 \\
(-1.236)\end{array}$ & $\begin{array}{c}2.287 \\
(-2.242)\end{array}$ & $\begin{array}{c}2.643 \\
(-3.177)\end{array}$ & $\begin{array}{c}5.206 \\
(-5.270)\end{array}$ & $\begin{array}{c}1.693 \\
(-0.462)\end{array}$ \\
\hline$(m g)$ & $\begin{array}{c}0.031 \\
(0.074)\end{array}$ & $\begin{array}{c}-0.001 \\
(0.100)\end{array}$ & $\begin{array}{c}-0.001 \\
(0.164)\end{array}$ & $\begin{array}{c}-0.003 \\
(0.285)\end{array}$ & $\begin{array}{c}0.128 \\
(0.136)\end{array}$ & $\begin{array}{c}0.195 \\
(-0.260)\end{array}$ & $\begin{array}{c}0.300 \\
(-0.215)\end{array}$ & $\begin{array}{c}0.465 \\
(-0.287)\end{array}$ & $\begin{array}{c}0.658 \\
(-0.743)\end{array}$ & $\begin{array}{c}0.413 \\
(-0.224)\end{array}$ \\
\hline$(m s)$ & $\begin{array}{c}0.020 \\
(0.112)\end{array}$ & $\begin{array}{c}-0.003 \\
(0.176)\end{array}$ & $\begin{array}{c}0.004 \\
(0.302)\end{array}$ & $\begin{array}{c}-0.004 \\
(0.551)\end{array}$ & $\begin{array}{c}0.077 \\
(0.101)\end{array}$ & $\begin{array}{c}0.380 \\
(-0.226)\end{array}$ & $\begin{array}{c}0.541 \\
(-0.400)\end{array}$ & $\begin{array}{c}0.762 \\
(-0.941)\end{array}$ & $\begin{array}{c}1.480 \\
(-1.703)\end{array}$ & $\begin{array}{c}0.473 \\
(-0.279)\end{array}$ \\
\hline$c$ & $\begin{array}{c}0.016 \\
(0.058)\end{array}$ & $\begin{array}{c}0.000 \\
(0.109)\end{array}$ & $\begin{array}{c}0.000 \\
(0.210)\end{array}$ & $\begin{array}{l}-0.004 \\
(0.412)\end{array}$ & $\begin{array}{c}0.063 \\
(0.039)\end{array}$ & $\begin{array}{c}0.138 \\
(-0.093)\end{array}$ & $\begin{array}{c}0.173 \\
(-0.208)\end{array}$ & $\begin{array}{c}0.344 \\
(-0.369)\end{array}$ & $\begin{array}{c}0.699 \\
(-0.652)\end{array}$ & $\begin{array}{c}0.181 \\
(-0.051)\end{array}$ \\
\hline$i$ & $\begin{array}{c}0.022 \\
(0.071)\end{array}$ & $\begin{array}{c}-0.001 \\
(0.109)\end{array}$ & $\begin{array}{l}-0.003 \\
(0.198)\end{array}$ & $\begin{array}{l}-0.007 \\
(0.372)\end{array}$ & $\begin{array}{c}0.098 \\
(0.132)\end{array}$ & $\begin{array}{c}0.219 \\
(-0.235)\end{array}$ & $\begin{array}{c}0.268 \\
(-0.297)\end{array}$ & $\begin{array}{c}0.485 \\
(-0.553)\end{array}$ & $\begin{array}{c}0.730 \\
(-0.913)\end{array}$ & $\begin{array}{c}0.368 \\
(-0.256)\end{array}$ \\
\hline$x$ & $\begin{array}{c}0.017 \\
(0.099)\end{array}$ & $\begin{array}{c}0.001 \\
(0.146)\end{array}$ & $\begin{array}{c}0.001 \\
(0.227)\end{array}$ & $\begin{array}{c}-0.002 \\
(0.368)\end{array}$ & $\begin{array}{c}0.077 \\
(0.069)\end{array}$ & $\begin{array}{c}0.261 \\
(-0.203)\end{array}$ & $\begin{array}{c}0.286 \\
(-0.376)\end{array}$ & $\begin{array}{c}0.552 \\
(-0.533)\end{array}$ & $\begin{array}{c}1.013 \\
(-0.654)\end{array}$ & $\begin{array}{c}0.271 \\
(-0.072)\end{array}$ \\
\hline$(m)$ & $\begin{array}{c}0.029 \\
(0.069)\end{array}$ & $\begin{array}{c}-0.002 \\
(0.095)\end{array}$ & $\begin{array}{c}0.001 \\
(0.158)\end{array}$ & $\begin{array}{c}-0.004 \\
(0.281)\end{array}$ & $\begin{array}{c}0.116 \\
(0.118)\end{array}$ & $\begin{array}{c}0.233 \\
(-0.219)\end{array}$ & $\begin{array}{c}0.255 \\
(-0.188)\end{array}$ & $\begin{array}{c}0.388 \\
(-0.414)\end{array}$ & $\begin{array}{c}0.549 \\
(-0.802)\end{array}$ & $\begin{array}{c}0.349 \\
(-0.192)\end{array}$ \\
\hline$i d$ & $\begin{array}{c}0.018 \\
(0.056)\end{array}$ & $\begin{array}{c}-0.002 \\
(0.098)\end{array}$ & $\begin{array}{c}0.000 \\
(0.185)\end{array}$ & $\begin{array}{l}-0.005 \\
(0.359)\end{array}$ & $\begin{array}{c}0.069 \\
(0.067)\end{array}$ & $\begin{array}{c}0.159 \\
(-0.118)\end{array}$ & $\begin{array}{c}0.204 \\
(-0.220)\end{array}$ & $\begin{array}{c}0.357 \\
(-0.418)\end{array}$ & $\begin{array}{c}0.707 \\
(-0.716)\end{array}$ & $\begin{array}{c}0.212 \\
(-0.100)\end{array}$ \\
\hline$e d$ & $\begin{array}{c}0.015 \\
(0.064)\end{array}$ & $\begin{array}{c}-0.001 \\
(0.122)\end{array}$ & $\begin{array}{c}0.000 \\
(0.240)\end{array}$ & $\begin{array}{l}-0.005 \\
(0.474)\end{array}$ & $\begin{array}{c}0.059 \\
(0.033)\end{array}$ & $\begin{array}{c}0.117 \\
(-0.099)\end{array}$ & $\begin{array}{c}0.193 \\
(-0.199)\end{array}$ & $\begin{array}{c}0.370 \\
(-0.346)\end{array}$ & $\begin{array}{c}0.704 \\
(-0.685)\end{array}$ & $\begin{array}{c}0.157 \\
(-0.039)\end{array}$ \\
\hline$g d p$ & $\begin{array}{c}0.013 \\
(0.040)\end{array}$ & $\begin{array}{c}-0.001 \\
(0.069)\end{array}$ & $\begin{array}{c}0.000 \\
(0.126)\end{array}$ & $\begin{array}{c}-0.005 \\
(0.238)\end{array}$ & $\begin{array}{c}0.054 \\
(0.037)\end{array}$ & $\begin{array}{c}0.094 \\
(-0.082)\end{array}$ & $\begin{array}{c}0.164 \\
(-0.127)\end{array}$ & $\begin{array}{c}0.272 \\
(-0.210)\end{array}$ & $\begin{array}{c}0.396 \\
(-0.482)\end{array}$ & $\begin{array}{c}0.163 \\
(-0.045)\end{array}$ \\
\hline
\end{tabular}


Table B2. Typical statistics of supply side series, full sample

\begin{tabular}{|c|c|c|c|c|c|c|c|c|c|c|}
\hline & \multicolumn{5}{|c|}{$\begin{array}{c}\text { Mean } \\
\text { (Standard deviation) }\end{array}$} & \multicolumn{5}{|c|}{$\begin{array}{l}\text { Maximum } \\
\text { (Minimum) }\end{array}$} \\
\hline & $d 1$ & $d 2$ & $d 3$ & $d 4$ & $\%$ & $d 1$ & $d 2$ & $d 3$ & $d 4$ & $\%$ \\
\hline$e g w$ & $\begin{array}{c}0.011 \\
(0.070)\end{array}$ & $\begin{array}{l}-0.001 \\
(0.090)\end{array}$ & $\begin{array}{c}0.002 \\
(0.143)\end{array}$ & $\begin{array}{l}-0.001 \\
(0.247)\end{array}$ & $\begin{array}{c}0.047 \\
(0.141)\end{array}$ & $\begin{array}{c}0.203 \\
(-0.219)\end{array}$ & $\begin{array}{c}0.246 \\
(-0.215)\end{array}$ & $\begin{array}{c}0.333 \\
(-0.295)\end{array}$ & $\begin{array}{c}0.564 \\
(-0.618)\end{array}$ & $\begin{array}{c}0.483 \\
(-0.387)\end{array}$ \\
\hline $\min$ & $\begin{array}{c}0.010 \\
(0.069)\end{array}$ & $\begin{array}{c}0.000 \\
(0.117)\end{array}$ & $\begin{array}{l}-0.001 \\
(0.215)\end{array}$ & $\begin{array}{l}-0.004 \\
(0.408)\end{array}$ & $\begin{array}{c}0.043 \\
(0.064)\end{array}$ & $\begin{array}{c}0.155 \\
(-0.144)\end{array}$ & $\begin{array}{c}0.204 \\
(-0.298)\end{array}$ & $\begin{array}{c}0.468 \\
(-0.433)\end{array}$ & $\begin{array}{c}0.826 \\
(-0.691)\end{array}$ & $\begin{array}{c}0.181 \\
(-0.086)\end{array}$ \\
\hline caf & $\begin{array}{c}0.010 \\
(0.283)\end{array}$ & $\begin{array}{l}-0.008 \\
(0.434)\end{array}$ & $\begin{array}{c}0.002 \\
(0.707)\end{array}$ & $\begin{array}{c}-0.011 \\
(1.215)\end{array}$ & $\begin{array}{c}0.065 \\
(0.141)\end{array}$ & $\begin{array}{c}0.661 \\
(-0.524)\end{array}$ & $\begin{array}{c}0.967 \\
(-0.869)\end{array}$ & $\begin{array}{c}1.567 \\
(-1.724)\end{array}$ & $\begin{array}{c}2.750 \\
(-3.048)\end{array}$ & $\begin{array}{c}0.458 \\
(-0.374)\end{array}$ \\
\hline$a g r$ & $\begin{array}{c}0.002 \\
(0.516)\end{array}$ & $\begin{array}{c}-0.007 \\
(0.729)\end{array}$ & $\begin{array}{c}-0.003 \\
(1.041)\end{array}$ & $\begin{array}{c}-0.009 \\
(1.509)\end{array}$ & $\begin{array}{c}0.052 \\
(0.048)\end{array}$ & $\begin{array}{c}0.903 \\
(-0.892)\end{array}$ & $\begin{array}{c}1.070 \\
(-1.076)\end{array}$ & $\begin{array}{c}1.915 \\
(-1.948)\end{array}$ & $\begin{array}{c}2.511 \\
(-2.307)\end{array}$ & $\begin{array}{c}0.177 \\
(-0.097)\end{array}$ \\
\hline $\operatorname{man}$ & $\begin{array}{c}0.010 \\
(0.041)\end{array}$ & $\begin{array}{l}-0.001 \\
(0.066)\end{array}$ & $\begin{array}{c}0.001 \\
(0.118)\end{array}$ & $\begin{array}{l}-0.003 \\
(0.221)\end{array}$ & $\begin{array}{c}0.039 \\
(0.051)\end{array}$ & $\begin{array}{c}0.116 \\
(-0.130)\end{array}$ & $\begin{array}{c}0.163 \\
(-0.197)\end{array}$ & $\begin{array}{c}0.356 \\
(-0.282)\end{array}$ & $\begin{array}{c}0.591 \\
(-0.565)\end{array}$ & $\begin{array}{c}0.187 \\
(-0.122)\end{array}$ \\
\hline com & $\begin{array}{c}0.016 \\
(0.083)\end{array}$ & $\begin{array}{l}-0.001 \\
(0.136)\end{array}$ & $\begin{array}{c}0.001 \\
(0.241)\end{array}$ & $\begin{array}{l}-0.005 \\
(0.445)\end{array}$ & $\begin{array}{c}0.067 \\
(0.060)\end{array}$ & $\begin{array}{c}0.204 \\
(-0.108)\end{array}$ & $\begin{array}{c}0.293 \\
(-0.232)\end{array}$ & $\begin{array}{c}0.460 \\
(-0.525)\end{array}$ & $\begin{array}{c}0.811 \\
(-0.985)\end{array}$ & $\begin{array}{c}0.236 \\
(-0.092)\end{array}$ \\
\hline con & $\begin{array}{c}0.013 \\
(0.074)\end{array}$ & $\begin{array}{c}0.000 \\
(0.113)\end{array}$ & $\begin{array}{l}-0.002 \\
(0.190)\end{array}$ & $\begin{array}{c}-0.005 \\
(0.337)\end{array}$ & $\begin{array}{c}0.056 \\
(0.085)\end{array}$ & $\begin{array}{c}0.178 \\
(-0.149)\end{array}$ & $\begin{array}{c}0.210 \\
(-0.245)\end{array}$ & $\begin{array}{c}0.347 \\
(-0.456)\end{array}$ & $\begin{array}{c}0.736 \\
(-0.620)\end{array}$ & $\begin{array}{c}0.304 \\
(-0.190)\end{array}$ \\
\hline tra & $\begin{array}{c}0.020 \\
(0.033)\end{array}$ & $\begin{array}{c}0.000 \\
(0.055)\end{array}$ & $\begin{array}{c}0.000 \\
(0.101)\end{array}$ & $\begin{array}{c}-0.003 \\
(0.190)\end{array}$ & $\begin{array}{c}0.080 \\
(0.044)\end{array}$ & $\begin{array}{c}0.091 \\
(-0.082)\end{array}$ & $\begin{array}{c}0.165 \\
(-0.130)\end{array}$ & $\begin{array}{c}0.296 \\
(-0.217)\end{array}$ & $\begin{array}{c}0.460 \\
(-0.512)\end{array}$ & $\begin{array}{c}0.212 \\
(-0.030)\end{array}$ \\
\hline fin & $\begin{array}{c}0.016 \\
(0.044)\end{array}$ & $\begin{array}{c}-0.001 \\
(0.073)\end{array}$ & $\begin{array}{c}0.001 \\
(0.132)\end{array}$ & $\begin{array}{c}-0.004 \\
(0.248)\end{array}$ & $\begin{array}{c}0.065 \\
(0.045)\end{array}$ & $\begin{array}{c}0.129 \\
(-0.093)\end{array}$ & $\begin{array}{c}0.136 \\
(-0.197)\end{array}$ & $\begin{array}{c}0.321 \\
(-0.307)\end{array}$ & $\begin{array}{c}0.628 \\
(-0.480)\end{array}$ & $\begin{array}{c}0.170 \\
(-0.043)\end{array}$ \\
\hline per & $\begin{array}{c}0.012 \\
(0.216)\end{array}$ & $\begin{array}{c}-0.003 \\
(0.370)\end{array}$ & $\begin{array}{c}0.001 \\
(0.673)\end{array}$ & $\begin{array}{c}-0.013 \\
(1.274)\end{array}$ & $\begin{array}{c}0.036 \\
(0.015)\end{array}$ & $\begin{array}{c}0.357 \\
(-0.361)\end{array}$ & $\begin{array}{c}0.706 \\
(-0.396)\end{array}$ & $\begin{array}{c}1.102 \\
(-1.036)\end{array}$ & $\begin{array}{c}1.534 \\
(-2.137)\end{array}$ & $\begin{array}{c}0.071 \\
(-0.017)\end{array}$ \\
\hline ood & $\begin{array}{c}0.006 \\
(0.003)\end{array}$ & $\begin{array}{c}0.000 \\
(0.003)\end{array}$ & $\begin{array}{c}0.000 \\
(0.004)\end{array}$ & $\begin{array}{c}0.000 \\
(0.005)\end{array}$ & $\begin{array}{c}0.026 \\
(0.009)\end{array}$ & $\begin{array}{c}0.012 \\
(-0.013)\end{array}$ & $\begin{array}{c}0.025 \\
(-0.021)\end{array}$ & $\begin{array}{c}0.026 \\
(-0.022)\end{array}$ & $\begin{array}{c}0.041 \\
(-0.022)\end{array}$ & $\begin{array}{c}0.040 \\
(-0.006)\end{array}$ \\
\hline$p u b$ & $\begin{array}{c}0.004 \\
(0.006)\end{array}$ & $\begin{array}{c}0.000 \\
(0.009)\end{array}$ & $\begin{array}{c}0.002 \\
(0.016)\end{array}$ & $\begin{array}{c}0.000 \\
(0.028)\end{array}$ & $\begin{array}{c}0.018 \\
(0.013)\end{array}$ & $\begin{array}{c}0.019 \\
(-0.026)\end{array}$ & $\begin{array}{c}0.026 \\
(-0.041)\end{array}$ & $\begin{array}{c}0.067 \\
(-0.068)\end{array}$ & $\begin{array}{c}0.135 \\
(0.105)\end{array}$ & $\begin{array}{c}0.040 \\
(-0.022)\end{array}$ \\
\hline$(d u t)$ & $\begin{array}{c}0.016 \\
(0.041)\end{array}$ & $\begin{array}{c}0.000 \\
(0.058)\end{array}$ & $\begin{array}{c}0.000 \\
(0.088)\end{array}$ & $\begin{array}{c}-0.001 \\
(0.136)\end{array}$ & $\begin{array}{c}0.065 \\
(0.049)\end{array}$ & $\begin{array}{c}0.107 \\
(-0.096)\end{array}$ & $\begin{array}{c}0.173 \\
(-0.116)\end{array}$ & $\begin{array}{c}0.289 \\
(-0.193)\end{array}$ & $\begin{array}{c}0.340 \\
(-0.458)\end{array}$ & $\begin{array}{c}0.186 \\
(-0.046)\end{array}$ \\
\hline vat & $\begin{array}{c}0.012 \\
(0.034)\end{array}$ & $\begin{array}{l}-0.001 \\
(0.058)\end{array}$ & $\begin{array}{l}-0.002 \\
(0.108)\end{array}$ & $\begin{array}{l}-0.004 \\
(0.204)\end{array}$ & $\begin{array}{c}0.051 \\
(0.034)\end{array}$ & $\begin{array}{c}0.079 \\
(-0.068)\end{array}$ & $\begin{array}{c}0.117 \\
(-0.110)\end{array}$ & $\begin{array}{c}0.215 \\
(-0.171)\end{array}$ & $\begin{array}{c}0.330 \\
(-0.372)\end{array}$ & $\begin{array}{c}0.134 \\
(-0.042)\end{array}$ \\
\hline cif & $\begin{array}{c}0.033 \\
(0.086)\end{array}$ & $\begin{array}{c}-0.004 \\
(0.128)\end{array}$ & $\begin{array}{c}0.000 \\
(0.221)\end{array}$ & $\begin{array}{c}-0.007 \\
(0.402)\end{array}$ & $\begin{array}{c}0.140 \\
(0.151)\end{array}$ & $\begin{array}{c}0.256 \\
(-0.177)\end{array}$ & $\begin{array}{c}0.318 \\
(-0.360)\end{array}$ & $\begin{array}{c}0.538 \\
(-0.658)\end{array}$ & $\begin{array}{c}1.055 \\
(-1.196)\end{array}$ & $\begin{array}{c}0.448 \\
(-0.201)\end{array}$ \\
\hline$g d p n r$ & $\begin{array}{c}0.010 \\
(0.053)\end{array}$ & $\begin{array}{c}-0.001 \\
(0.086)\end{array}$ & $\begin{array}{c}0.000 \\
(0.153)\end{array}$ & $\begin{array}{l}-0.001 \\
(0.284)\end{array}$ & $\begin{array}{c}0.043 \\
(0.056)\end{array}$ & $\begin{array}{c}0.196 \\
(-0.096)\end{array}$ & $\begin{array}{c}0.265 \\
(-0.169)\end{array}$ & $\begin{array}{c}0.341 \\
(-0.428)\end{array}$ & $\begin{array}{c}0.593 \\
(-0.725)\end{array}$ & $\begin{array}{c}0.218 \\
(-0.087)\end{array}$ \\
\hline$g d p n n r$ & $\begin{array}{c}0.013 \\
(0.037)\end{array}$ & $\begin{array}{c}-0.001 \\
(0.064)\end{array}$ & $\begin{array}{c}0.000 \\
(0.119)\end{array}$ & $\begin{array}{c}-0.004 \\
(0.228)\end{array}$ & $\begin{array}{c}0.052 \\
(0.035)\end{array}$ & $\begin{array}{c}0.080 \\
(-0.070)\end{array}$ & $\begin{array}{c}0.129 \\
(-0.116)\end{array}$ & $\begin{array}{c}0.222 \\
(-0.196)\end{array}$ & $\begin{array}{c}0.340 \\
(-0.419)\end{array}$ & $\begin{array}{c}0.142 \\
(-0.045)\end{array}$ \\
\hline others & $\begin{array}{c}0.013 \\
(0.034)\end{array}$ & $\begin{array}{l}-0.001 \\
(0.057)\end{array}$ & $\begin{array}{c}0.000 \\
(0.105)\end{array}$ & $\begin{array}{c}-0.004 \\
(0.199)\end{array}$ & $\begin{array}{c}0.052 \\
(0.034)\end{array}$ & $\begin{array}{c}0.078 \\
(-0.068)\end{array}$ & $\begin{array}{c}0.112 \\
(-0.110)\end{array}$ & $\begin{array}{c}0.204 \\
(-0.167)\end{array}$ & $\begin{array}{c}0.316 \\
(-0.357)\end{array}$ & $\begin{array}{c}0.136 \\
(-0.045)\end{array}$ \\
\hline$g d p$ & $\begin{array}{c}0.013 \\
(0.040)\end{array}$ & $\begin{array}{l}-0.001 \\
(0.069)\end{array}$ & $\begin{array}{c}0.000 \\
(0.126)\end{array}$ & $\begin{array}{l}-0.005 \\
(0.238)\end{array}$ & $\begin{array}{c}0.054 \\
(0.037)\end{array}$ & $\begin{array}{c}0.094 \\
(-0.082)\end{array}$ & $\begin{array}{c}0.164 \\
(-0.127)\end{array}$ & $\begin{array}{c}0.272 \\
(-0.210)\end{array}$ & $\begin{array}{c}0.396 \\
(-0.482)\end{array}$ & $\begin{array}{c}0.163 \\
(-0.045)\end{array}$ \\
\hline
\end{tabular}

Source: Author's computations. 
